\title{
Publications by L.A.S. Johnson: 1949-1995
}

1. Garden, J. \& Johnson, L.A.S. (1949) Proposals for conservation of the names of three Australian genera. Australasian Herbarium News No. 5: 3-5.

2. Garden, J. \& Johnson, L.A.S. (1950) Microstrobos, a new name for a Podocarpaceous genus. Contr. New S. Wales Natl. Herb. 1: 315-321.

3. Johnson, L.A.S. (1950) A hitherto undescribed Kochia (Chenopodiaceae). Contr. New S. Wales Natl. Herb. 1: 343-345.

4. Johnson, L.A.S. (1950) Valid publication and nomina alternativa. Austral. Herb. News No. 7: 1-4.

5. Johnson, L.A.S. (1952) Nomenclature. Austral. Journ. Sci. 14: 184-186.

6. Garden, J. \& Johnson, L.A.S. (1954) Additional note on the proposed conservation of the generic name Pherosphaera. Taxon 3: 150.

7. Johnson, L.A.S. (1954) Macadamia ternifolia F. Muell. and a related new species. Proc. Linn. Soc. New S. Wales 79: 15-18.

8. Johnson, L.A.S. (1954) Tropical eucalypts. Australasian Herbarium News 14: 7-9.

9. Johnson, L.A.S. (1957) Two new species of Persoonia. Vict. Nat. 73: 160-161.

10. Johnson, L.A.S. (1957) A review of the family Oleaceae. Contr. New S.Wales Natl. Herb. 2: 395-418.

11. Johnson, L.A.S. (1958) Nestegis (family Oleaceae). In O. Degener, Flora Hawaiiensis. (3 pages).

12. Johnson, L.A.S. (1959) The families of cycads and the Zamiaceae of Australia. Proc. Linn. Soc. New S. Wales. 84: 64-117.

13. Johnson, L.A.S. (1961) Zamiaceae. Flora of New S. Wales. 1: 21-41.

14. Pryor, L.D. \& Johnson, L.A.S. (1962) The status and significance of the hybrid Eucalyptus marginata Sm. X E. megacarpa F. Muell. Austral. Journ. Bot. 10: 129-133.

15. Evans, O.D. \& Johnson, L.A.S. (1962) Palmae. Flora of New S. Wales 21: 1-6.

16. Johnson, L.A.S. (1962) Taxonomic notes on Australian plants. Contr. New S. Wales Natl. Herb. 3: 93-102.

17. Johnson, L.A.S. (1962) Studies in the taxonomy of Eucalyptus. Contr. New S. Wales Natl. Herb. 3: $103-126$.

18. Johnson, L.A.S. \& Briggs, B.G. (1962) Taxonomic and cytological notes on Acetosa and Acetosella in Australia. Contr. New S. Wales Natl. Herb. 3: 165-169.

19. Johnson, L.A.S. \& Evans, O.D. (1963) A revision of the Restio gracilis complex. Contr. New S. Wales Natl. Herb. 3: 200-217.

20. Johnson, L.A.S. \& Evans, O.D. (1963) Geographic races in Restio tetraphyllus Labill. Contr. New S. Wales Natl. Herb. 3: 218-222.

21. Johnson, L.A.S. \& Evans, O.D. (1963) Intrageneric groups and new species in Lepyrodia. Contr. New S. Wales Natl. Herb. 3: 223-227.

22. Johnson, L.A.S. (1963) Cytological and taxonomic notes on Zamiaceae. Contr. New S. Wales Natl. Herb. 3: 235-240.

23. Johnson, L.A.S. (1963) New species of Juncus in Australia and New Zealand. Contr. New S. Wales Natl. Herb. 3: 241-244.

24. Johnson, L.A.S. \& Briggs, B.G. (1963) Evolution in the Proteaceae. Austral. J. Bot. 11: 21-61.

25. Johnson, L.A.S. (1965) The fruit of Eucalyptus preissiana. A corrected interpretation. Vict. Nat. 82: 223-224.

26. Johnson, L.A.S. \& Evans, O.D. (1966) Restionaceae. Flora of New S. Wales 25: 2-28.

27. Evans, O.D. \& Johnson, L.A.S. (1966) Philydraceae. Flora of New S. Wales 31: 3-6.

28. Johnson, L.A.S. (1967) Casuarina monilifera L. Johnson, sp. nov. In W.M. Curtis, The Student's Flora of Tasmania, 3: 651-653.

29. Pryor, L.D., Johnson, L.A.S., Whitecross, M.I. \& McGillivray, D.J. (1967) The perianth and the taxonomic affinities of Eucalyptus cloëziana F. Muell. Austral. J. Bot. 15: 145-149.

30. Briggs, B.G. \& Johnson, L.A.S. (1968) The status and relationships of the Australasian species of Typha. Contr. New S. Wales Natl. Herb. 4: 57-68.

31. Johnson, L.A.S. \& Evans, O.D. (1968) New species in Eleocharis. Contr. New S. Wales Natl. Herb. 4: $70-72$

32. Johnson, L.A.S. (1968) Rainbow's End: the quest for an optimal taxonomy. Presidential address. Proc. Linn. Soc. New S. Wales 93: 8-45.

33. Johnson, L.A.S. (1970) Biosystematics alive? - a discussion. Taxon 19: 152-153.

34. Johnson, L.A.S. (1970) [Republication of] Rainbow's End: the quest for an optimal taxonomy (with addendum). Syst. Zool. 19: 203-239.

35. Pryor, L.D. \& Johnson, L.A.S. (1971) A Classification of the Eucalypts (Australian National University: Canberra).

36. Johnson, L.A.S. \& Briggs, B.G. (1971) Unplanted trees: the value of natural regrowth. Agric. Gaz. New S. Wales 82: 34-35. 
37. Johnson, L.A.S. (1972) Science and non-science in systematics. 14th Intl. Congr. Entomology, Abstracts: 12-13.

38. Johnson, L.A.S. (1972) New species and subspecies of Casuarina in Western Australia. Nuytsia 1: 261-265.

39. Johnson, L.A.S. \& Blaxell, D.F. (1972) New taxa and combinations in Eucalyptus - I. Contr. New S. Wales Natl. Herb. 4: 284-290.

40. Johnson, L.A.S. (1972) Evolution and classification in Eucalyptus. Proc. Linn Soc. New S. Wales 97: $11-29$.

41. Johnson, L.A.S. \& Cutler, D.F. (1973) Empodisma: a new genus of Australasian Restionaceae. Kew Bull. 28: 381-385.

42. Lander, N.S. \& Johnson, L.A.S. 1973. A new Australian species of Maytenus. Contr. New S. Wales Natl. Herb. 4: 373-376.

43. Johnson, L.A.S. \& Evans, O.D. (1973) Cyperus brevifolius and an allied species in Eastern Australia. Contr. New S. Wales Natl. Herb. 4: 378.

44. Johnson, L.A.S. \& Blaxell, D.F. (1973) New taxa and combinations in Eucalyptus - II. Contr. New S. Wales Natl. Herb. 4: 379-383.

45. Johnson, L.A.S. \& Blaxell, D.F. (1973) New taxa and combinations in Eucalyptus - III. Contr. New S. Wales Natl. Herb. 4: 453-456.

46. Johnson, L.A.S. (1973) New fund for research on Australian plants. Austral. Plants 7: 171-197.

47. Johnson, L.A.S. (1973) Recent research on the classification of Australian plants. Austral. Plants 7: 173-174.

48. Lander, N.S. \& Johnson, L.A.S. (1975) Australian species of Celastrus. Telopea 1: 33-39.

49. Johnson, L.A.S. \& McGillivray, D.J. (1975) [description of] Grevillea rivularis. (In D.J. McGillivray: Australian Proteaceae: new taxa and notes.) Telopea 1: 23.

50. Briggs, B.G., Hyland, B.P.M. \& Johnson, L.A.S. (1975) Sphalmium, a distinctive new genus of Proteaceae from North Queensland. Austral. J. Bot. 23: 165-172.

51. Johnson, L.A.S. (1975) Comments on article 'The challenge of urban forestry'. Architecture in Australia 64: 61-62.

52. Johnson, L.A.S. \& McGillivray, D.J. (1975) Conospermum Sm. (Proteaceae) in eastern Australia. Telopea 1: 58-65.

53. Johnson, L.A.S. \& Briggs, B.G. (1975) On the Proteaceae - the evolution and classification of a southern family. Bot. J. Linn. Soc. London. 70: 83-182.

54. Johnson, L.A.S. (1976) Problems of species and genera in Eucalyptus (Myrtaceae). Plant Syst. Evol. 125: 155-167.

55. Johnson, L.A.S. (1976) Review of Flora Europaea, vol. 4, edited by T.G. Tutin and others. Search 8: 289.

56. Johnson, L.A.S. (1977) Newcomers to Australia scrutinised. Review of P.H. Raven \& T. Engelhorn Raven, The genus Epilobium (Onagraceae) in Australia. Syst. Bot. 2: 87-88.

57. Johnson, L.A.S. (1977) A rich and unfamiliar flora. Austral. Natural History 19: 57-61.

58. Johnson, L.A.S. (1978) The plant family Proteaceae. Austral. Plants 9: 303-311.

59. Briggs, B.G. \& Johnson, L.A.S. (1979) Evolution in the Myrtaceae - evidence from inflorescence structure. Proc. Linn. Soc. New S. Wales 102: 157-256.

60. Johnson, L.A.S. \& Alford, D. (1979) Royal Botanic Gardens, Sydney. Australian Parks \& Recreation, May: 25-26.

61. Johnson, L.A.S. \& Blaxell, D.F. (1980) New taxa and combinations in Eucalyptus - IV. Telopea 1: 395-397.

62. Johnson, L.A.S. (1980) Notes on Casuarinaceae. Telopea 2: 83-84.

63. Johnson, L.A.S. (1980) The scientific role of botanic gardens. Pp. 18-23 in Proceedings of the Conference on the Development of a Botanic Gardens, Coffs Harbour Jetty (University of New England).

64. Johnson, L.A.S. \& Wilson, K.L. (1981) Casuarinaceae, then and now. In Abstracts of the XIII International Botanical Congress: 278 (Sydney).

65. Johnson, L.A.S. \& Briggs, B.G. (1981) Composition and relationships of Myrtaceae. In Abstracts of the XIII International Botanical Congress: 132 (Sydney).

66. Johnson, L.A.S. (1981) Eucalypts (genus Eucalyptus). In Oxford Encyclopedia of Trees of the World: 214-218 (Oxford University Press).

67. Johnson, L.A.S. \& Briggs, B.G. (1981) Three old southern families - Myrtaceae, Proteaceae and Restionaceae. Pp. 427-469 in A. Keast (ed.), Ecological Biogeography of Australia. (The Hague: W. Junk).

68. Pryor, L.D. \& Johnson, L.A.S. (1981) Eucalyptus, the universal Australian. Pp. 501-536 in A. Keast (ed.), Ecological Biogeography of Australia. (The Hague: W. Junk).

69. Johnson, L.A.S. (1982) The Leguminosae. (Review) Science 216: 1402-1403.

70. Johnson, L.A.S. (1982) Notes on Casuarinaceae II. J. Adelaide Bot. Gard. 6: 73-82.

71. Johnson, L.A.S. \& Briggs, B.G. (1982) Inflorescences - a further comment. Austral. Syst. Bot. Soc. Newsletter 30: 57-58.

72. Rodd, A.N. \& Johnson, L.A.S. (1982) 'The Royal Botanical Garden' in Sydney. Gürtner Meister No. 2: 26-24. 
73. Johnson, L.A.S. (1983) Casuarinaceae. In P. van Royen, The Alpine Flora of New Guinea 4: 2405-2408.

74. Johnson, L.A.S. \& Briggs, B.G. (1983) Myrtaceae - comments on comments: Taxon 32: 103-105.

75. Johnson, L.A.S. \& Wilson, K.L. (1983) Casuarinaceae (pp. 66-77) and Juncaceae (pp. 362-364) in Morley, B. and Toelken, H. (eds), Flowering Plants in Australia. (Rigby).

76. Johnson, L.A.S. \& Briggs, B.G. (1983) Myrtaceae (pp. 175-185); Proteaceae (pp. 238-244); Restionaceae (pp. 371-373); Flagellariaceae (pp. 375-376); Hanguanaceae (p. 376). In Morley, B. \& Toelken, H. (eds), Flowering Plants in Australia. (Rigby).

77. Johnson, L.A.S. \& Briggs, B.G. (1984) Myrtales and Myrtaceae - a phylogenetic analysis. Ann. Missouri Bot. Gard. 71: 700-756.

78. Johnson, L.A.S. \& Briggs, B.G. (1985) Alexgeorgea nitens, a new combination in Restionaceae. Telopea 2: 781-782.

79. Briggs, B.G. \& Johnson, L.A.S. (1986) A new species and a new genus of Restionaceae from Tasmania. Telopea 2: 737-740.

80. Thompson, J. \& Johnson, L.A.S. (1986) Callitris glaucophylla, Australia's 'White Cypress Pine' a new name for an old species. Telopea 2: 731-736.

81. Harden, G.J. \& Johnson, L.A.S. (1986) A note on Diploglottis australis (G. Don) Radlk. Telopea 2: 745-748.

82. Johnson, L.A.S. (1987) Aspects of the systematics of the eucalypts. Austral. Syst. Bot. Soc. Newsletter 53: 91-93.

83. Johnson, L.A.S. (1988) Notes on Casuarinaceae III: the new genus Ceuthostoma. Telopea 3: 133-137.

84. Wilson, K. \& Johnson, L.A.S. (1988) Smilax glyciphylla. Austral. Syst. Bot. Soc. Newsletter 57: 1-3.

85. Johnson, L.A.S. (1989) Models and reality: doctrine and practicality in classification. Plant Systematics and Evolution 168: 95-108.

86. Adolphi, K., Seybold S. \& Johnson, L.A.S. (1989) Proposal to conserve 8878 Brachycome Cass. (Asteraceae). Taxon 38: 511-513.

87. Wilson, K.L. \& Johnson, L.A.S. (1989) Casuarinaceae: a synopsis. In Crane, P.R. \& Blackmore, S. (eds), "Higher" Hamamelidae. Evolution, systematics, and fossil history of the Hamamelidae, 2: 167-188 (Oxford: Clarendon Press).

88. Briggs, B.G., Johnson, L.A.S., \& Krauss, S.L. (1990) The species of Alexgeorgea, a Western Australian genus of the Restionaceae. Austral. Syst. Bot. 3: 751-758.

89. Wilson, K.L. \& Johnson, L.A.S. (1990) Cycadatae. In Kubitzki, K. (ed.), The families and genera of vascular plants, I. Pteridophytes and gymnosperms: 362-377. (Berlin: Springer).

90. Johnson, L.A.S. (1991) New Australian taxa in Juncus (Juncaceae). In M.R. Banks (ed.), Aspects of Tasmanian botany, Winifred Curtis Memorial Volume: 35-46 (Royal Society of Tasmania: Hobart).

91. Johnson, L.A.S., \& Briggs, B.G. (1991) The two Tasmanian species of Calorophus. In M.R. Banks (ed.), Aspects of Tasmanian Botany, Winifred Curtis Memorial Volume: 47-51. (Royal Society of Tasmania: Hobart).

92. Krauss, S.L. \& Johnson, L.A.S. (1991) A revision of the complex species Persoonia mollis (Proteaceae). Telopea 4: 185-199.

93. Weston, P.H. \& Johnson, L.A.S. (1991) Taxonomic changes in Persoonia (Proteaceae) in New South Wales. Telopea 4: 269-306.

94. Hill, K.D. \& Johnson, L.A.S. (1992) Systematic studies in the eucalypts. 5. New taxa and combinations in Eucalyptus (Myrtaceae) in Western Australia. Telopea 4: 561-634.

95. Briggs, B.G. \& Johnson, L.A.S. (1993) Systematics and evolution of Australian Restionaceae - a changing scene. In Southern Temperate Ecosystems: Origin and Diversification, conference abstracts: 26.

96. Briggs, B.G, Johnson, L.A.S., Porter, C. \& Krauss, S.L. (1993) Resolving polyphyletic assemblages in east Gondwanan Restionaceae. XV International Botanical Congress, Yokohama, Abstracts: 235.

97. Briggs, B.G. \& Johnson, L.A.S. (1993) Classification of Australian and other non-African Restionaceae. P. 23 in Monocotyledons: an international symposium, abstracts (Royal Botanic Gardens Kew).

98. Johnson, L.A.S. (1993) New species of Juncus (Juncaceae) in eastern Australia. Telopea 5: 309-318.

99. Hall, N. \& Johnson, L.A.S. (1993) The Names of Acacias of New South Wales with a Guide to Pronunciation of Botanical Names (Royal Botanic Gardens: Sydney).

100. Johnson, L.A.S. \& Briggs, B.G. (1994) Calorophus erostris (C.B. Clarke) L.A.S. Johnson, \& B.G. Briggs, comb. nov. (Restionaceae). P. 425 in Curtis, W.M. \& Morris, D.I., The Students Flora of Tasmania, part 4B.

101. Johnson, L.A.S. \& Morris, D.I. (1994) Allocasuarina duncanii, a new species in Allocasuarina section Cylindropitys (Casuarinaceae). Telopea 5: 793-794.

102. Hill, K.D. \& Johnson, L.A.S. (1994) Systematic studies in the eucalypts. 6 . A revision of the coolibahs, Eucalyptus subgenus Symphyomyrtus section Adnataria series Oliganthae subseries Microthecosae (Myrtaceae). Telopea 5: 743-771.

103. Hill, K.D. \& Johnson, L.A.S. (1995) Systematic studies in the eucalypts. 7. A revision of the bloodwoods, genus Corymbia (Myrtaceae). Telopea 6: 185-504. 


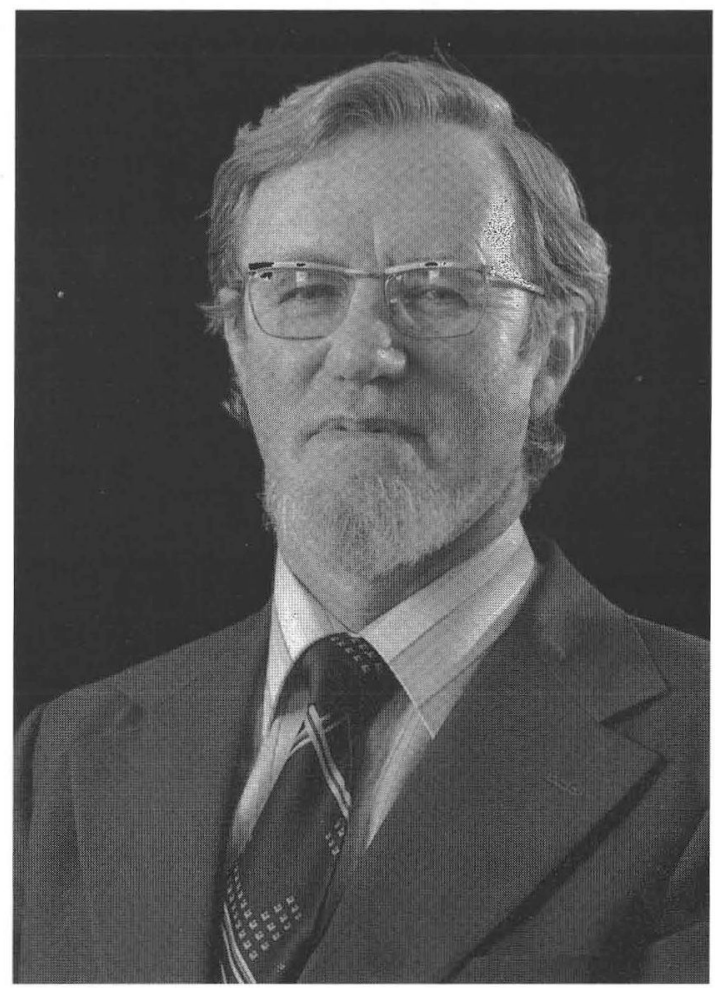

\section{Dedication}

This issue of Telopea is published in honour of Dr Lawrence Alexander Sidney Johnson following the occasion of his 70th birthday. Lawrie joined the staff of the National Herbarium of New South Wales as a botanist in 1948 and went on to be Director of the Royal Botanic Gardens, a position he held for over 13 years. Although now formally retired, he continues to make major contributions in plant systematics. 